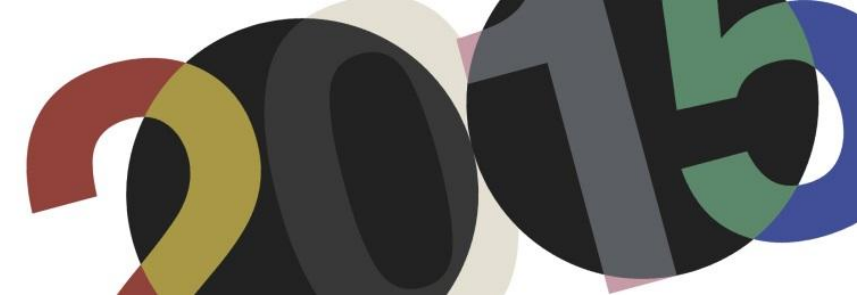

DOI: http://dx.doi.org/10.4995/LC2015.2015.949

\title{
MONUMENTALIZING MODERN MOBILITY
}

\author{
C.E. Comas
}

Universidade Federal do Rio Grande do Sul, Porto Alegre, Brasil

\begin{abstract}
The inhabitable viaduct is one of the most intriguing design proposals of Le Corbusier. Scholarly attention has focused upon the curvilinear megastructures designed for Rio de Janeiro and Algiers and their connection to the Ville Radieuse, downplaying the introduction of the inhabitable viaduct in São Paulo, and its connection with earlier proposals for Montevideo and Buenos Aires, the Plan Voisin and Ville Contemporaine, when Le Corbusier himself suggested that all these designs make up a sequence. The inhabitable viaduct has been understood as a reaction to non-European landscape and the airplane view, standing for a new sense of the organic in Le Corbusier's work. A closer inspection of these designs along with Le Corbusier's pertinent texts and imagery suggests that his architecture from 1929 onwards changes in degree rather than nature. The genesis of the inhabitable viaduct is seen as part of a sequence of topological transformations, informed by specific but generalizable site conditions and a host of precedents, but also, and primarily, as an alternative in Le Corbusier's controversial quest for monumentalizing the modern metropolis.
\end{abstract}

Resumen: El viaducto habitable es una de las propuestas más intrigantes de Le Corbusier. Los estudiosos han concentrado su atención en las mega-estructuras curvilíneas proyectadas para Río de Janeiro y Argelia y en sus conexiones con la Ville Radieuse, menospreciando la introducción del viaducto habitable en São Paulo, y su conexión con las propuestas anteriores para Montevideo y Buenos Aires, el Plan Voisin y Ville Contemporaine, cuando Le Corbusier mismo sugirió que todos eses proyectos forman una secuencia. El viaducto habitable ha sido entendido como una reacción al paisaje no-europeo y a la vista del avión, indicando un sentido nuevo de lo orgánico en la obra de Le Corbusier. Una inspección mas detenida de eses proyectos a la luz de textos e imágenes pertinentes del arquitecto sugiere que su arquitectura del 1929 en adelante sufre un cambio de énfasis y no de naturaleza. La génesis del viaducto habitable se ve aquí como parte de una secuencia de transformaciones topológica, que son informadas tanto por condiciones de situación a la vez específicas y susceptible de generalización cuanto por un conjunto de precedentes, pero también, y primariamente, como una alternativa en la búsqueda controvertida de Le Corbusier por monumentalizar la metrópolis moderna.

Keywords: Inhabitable viaduct/South America/ Algiers/ Monumentality/ Landscape/ Urbanism.

Palabras clave: Viaducto habitable/ Suramerica/ Argelia/ Monumentalidad/ Paisaje/ Urbanismo.

\section{Practical applications and ideal schemes}

Images of the Fiat Lingotto factory (1916-1922) in Turin illustrate the last chapter of Vers une architecture, ${ }^{1}$ but it was not until 1934 that Le Corbusier visited the building designed by engineer Giacomo Mattè-Trucco, and drove a car in the test track on its roof. Later, he said:

"The Fiat factory is more advanced than urbanism in our mechanized age. The freeway on the roof, for example, offers evidence of the modern technical possibilities. It is no longer a dream but a fact that certain cities, such as Genoa, Algiers, and Rio de Janeiro, could be saved from the disaster that threats them by constructing large

\footnotetext{
${ }^{1}$ Le Corbusier. Vers une architecture (Paris: Crès, 1923), p. 242.
} 
freeways at great height (like the Fiat track) on standard structures, allowing the cities to provide housing for a large population in optimal conditions.",2

The factory validated the inhabitable viaducts in his designs for two of those cities. He submitted his Plan Obus for Algiers ${ }^{3}$ after a first visit for conferences in 1931. It was an attempt both to get and enlarge the commission for redesigning the Quartier de la Marine, scheduled for demolition. His first design for Rio followed proposals for Buenos Aires, Montevideo and São Paulo, all done during a three-month long trip for conferences in 1929 and published immediately ${ }^{4}$. A second design for Rio was worked out in Paris in 1930 but published later ${ }^{5}$. Le Corbusier hoped to get commissions in South America too. Both suburbanization and vertical redevelopment were increasing in the cities he visited. Mario Palanti had designed Palacio Barolo (1919-1923), the tallest building in Buenos Aires, and Palacio Salvo (1923-1928), the tallest building in Montevideo ${ }^{6}$. Le Corbusier called the latter a "young skyscraper wrapped up in twisted decorative trimmings", despising its bodywork, but not its chassis. FIG 1 . He sought a "unity of system":

"I will implicate in the same consequence Buenos Aires, Montevideo d'Uruguay, São Paulo and Rio. Same principle, but deep diversity in the application of the principle. " 8

The ideal scheme for the Ville Contemporaine of 1922 is implied in that statement, along with its corollary, the 1925 Plan Voisin for Paris, and its variant, the Ville Radieuse of 1930. The diversity in the application of the principle paralleled the diversity of situations. Buenos Aires and Montevideo faced the River Plate on Spanish grids, with wide, straight streets fit for motor traffic. São Paulo and Rio mixed grids and winding, narrow streets in Portuguese style. São Paulo was a radio-concentric city built inland upon the "sinuosities" of a "nipplelike plateau," while Rio was a linear city stretched between mountains that "advanced toward the sea like the fingers of a hand". Built on slopes, Algiers faced the Mediterranean with the Kabylie Hills and Atlas Mountains behind. The boulevards of the French colonial city contrasted with the Casbah and its dense maze of narrow alleys.

The sequence of sites makes up a typology. Ville Contemporaine, Plan Voisin and Ville Radieuse deal with a square plain. Buenos Aires features a square plateau, one side raised along water. Montevideo features an elongated trapezoidal promontory prolonging a square plateau, a ridge establishing their common axis. São

\footnotetext{
${ }^{2}$ Willy Boesiger. Le Corbusier et Pierre Jeanneret. Oeuvre complète de 1929-1934. $13^{\text {th }}$ ed (Zurich: Editions d'Architecture/ Edition Girsberger, 1995), p. 202. All translations from the French are from the author, unless otherwise noted.

${ }^{3}$ Le Corbusier, "Plan d'aménagement de la ville d'Alger, 1931-1932”. L'Architecture Vivante (Automne-Hiver 1932), pp. 59, 15-21.

${ }^{4}$ Le Corbusier, Précisions sur un état present de l'architecture et de l'urbanisme (Paris: Vincent, Fréal, 1930). See also Cecilia Rodrigues dos Santos, and others. Le Corbusier e o Brasil (São Paulo: Projeto/Tessela, 1987); Fernando Pérez Oyarzun (ed.) Le Corbusier y Suramérica (Santiago: Ediciones ARQ, 1999); Jorge Francisco Liernur and Pablo Pschepiurca. La red austral. Obras y proyectos de Le Corbusier y sus discípulos en Argentina 1924-1965. Buenos Aires: Universidad Nacional de Quilmes, 2008; Ramon Gutierrez (ed.). Le Corbusier en el Río de la Plata, 1929 (Buenos Aires: Cedodal; Montevideo: FARQ Universidad de la Republica, 2009).

${ }^{5}$ Le Corbusier, La ville radieuse: Éléments d'une doctrine d'urbanisme pour l'équipement de la civilisation machiniste (Boulogne-sur-Seine, France: Éditions de L'Architecture d'aujourd'hui, 1935), p. 225.

${ }^{6}$ Leonel Contreras. Rascacielos porteños (Buenos Aires: Gobierno de la Ciudad de Buenos Aires, 2005), pp. 67-78 for Palacio Barolo, pp. 79-92 for Salvo. See also Sebastián Alonso, and others. 5 narrativas, 5 edificios (Montevideo: Ministerio de Educación y Cultura, 2010), p. 14-59.

${ }^{7}$ Le Corbusier. Précisions, p. 238.

${ }^{8}$ Idem.

${ }^{9}$ Le Corbusier, Précisions, pp. 234-241.
} 
Paulo presents a surface rather regularly embossed in low relief in a gridlike pattern. A mix of lowlands and fingerlike distribution of promontories, Rio presents a surface rather irregularly embossed in high relief with a radial pattern. Algiers features a flattened promontory approximating an oval truncated cone cut in half lengthwise. In Buenos Aires, Le Corbusier said his 1915 Maison Dom-ino updated the seventeenth-century Flemish béguinage ${ }^{10}$, and proposed a Plan Voisin for the Argentine capital ${ }^{11}$, aware that its flat ground echoed that of the Low Countries and Paris. Comparing the Carioca to the Alpine landscape, he later counted among "the balconies of the world" the Valais, "in front of the Lake Geneva and the mountains," and Rio, "between disheveled spurs". ${ }^{12}$

The cruciform skyscrapers suggested for Buenos Aires replicate those in Ville Contemporaine and Plan Voisin, but they rise from a boxy two-story base advancing into the river. The roof of this artificial promontory prolongs the level ground of the existing city and the surrounding pampas, which extend westward as far as the Andes. The axis of the composition runs next and parallel to the avenue connecting the presidential palace by the river to the Congress close to Palacio Barolo. The coastal boulevard and its branches insinuate a handwritten X, bringing to mind the diagonal avenues of Ville Contemporaine. FIG. 2 The seascrapers suggested for Montevideo came in two versions. The bolder one shows a T-shaped office building that touches the sea at one extremity and both seizes and prolongs the natural promontory. Its roof slab abuts the city's leveled main avenue generating a Latin cross. Palacio Salvo appears misplaced at one end of that avenue, which extends into the road to the hinterland. FIG. 3 The tamer version shows a single slab building advancing into the water. FIG. 4

The Brazilian proposals accentuated the engagement with the landscape at the scale of the whole city and the articulation of movement in a regional basis. The first inhabitable viaducts stand straight on São Paulo's curvaceous ground. They are multiuse structures, earthscrapers, to be filled with housing or offices. One meets the road to the port of Santos; another, the road to Rio. They are rulers that intersect generating a Greek cross like the cardo and decumanus of Roman camps. Near the crossing, they backdrop São Paulo's brand-new skyscrapers, retooling the city's business core. In the first Rio design, two curved earthscrapers share an intermediary segment, resembling a handwritten X, akin to the coastal boulevard and its branches in Buenos Aires. The longest connects Copacabana with the road to São Paulo. The shortest faces the shoreline, in the form of an expanded Lorraine cross whose triple bars shelter business at the Calabouço Point landfill and balance Sugarloaf Mountain at the other end. An extension of this branch becomes a bridge to Niterói across Guanabara Bay. FIG. 5, 6 The 1930 variant features an inhabitable viaduct parallel to the beaches. The 20 meters wide freeway runs 100 meters above sea level, with garages underneath; fifteen floors of infill housing start at 40 meters. FIG. 7

The first Plan Obus for Algiers suggests an expanded Lorraine cross with quadruple bars. Slightly deviated from a radial generator of the slope, a standard viaduct 160 meters above sea level joins the plateau of Fortl'Empereur to the rooftop of the 31-story office building at the Quartier de la Marine, condensing the city's new business core and connecting it to the hinterland. Two straight slab buildings cross that man-made axis at the plateau, anchoring a loop of curving rédents on each side of the viaduct, superimposed earthscrapers and 14story skyscrapers. The intermediary, covered vehicular streets are level with the deck of the standard viaduct. Another curving earthscraper runs parallel to the coast with a roof freeway 100 meters above sea level. That 28 kilometers long, 26 meters wide inhabitable viaduct connects Saint-Eugène to the north and Hussein-Dey to the south passing under the standard viaduct. It bends at its two extremities, descending to join the parallel coastal

\footnotetext{
${ }^{10}$ Le Corbusier. Précisions, p. 94.

${ }^{11}$ Le Corbusier. Précisions, pp. 167-213.

${ }^{12}$ Le Corbusier. Sur les quatre routes. (Paris: Gallimard, 1941), p. 38.
} 
corniche 10 meters above sea level, which gives access by below to the office building. The vehicular connection between Fort l'Empereur and the Quartier de la Marine- and hence, that between the city and its territory- is made through banks of elevators; as Antoine Picon observed ${ }^{13}$, Le Corbusier borrows from both garage managers and engineers. FIG. 8

The covered vehicular streets in the Fort l'Empereur rédents are branch roads. The structure is of the standard Dom-ino type both there and in the coastal highway, at times replaced by huge arches giving way to existing streets. The floor slabs of the inhabitable viaducts were termed artificial sites. Termed interior streets, doubleloaded corridors give access to internal plots of differing widths. Balconies appear in the coastal inhabitable viaduct planned for a low-income population, but only at the upscale rédents the plots are wide enough to allow for both balconies and lateral setbacks of varying dimensions, resulting in picturesque facades that validate Le Corbusier's claim to these buildings being vertical garden cities, offering absolute diversity within unity.

"Every architect will build his villa as he likes; what matters to the whole if a Moorish-style villa flanks another in Louis XVI or in Italian renaissance?",14

The decorative trimmings favored by Palanti are ordered by the serial succession of columns and the sharp slab borders. The ground at Fort l'Empereur is rather untouched. FIG. 9

\section{Topological transformations}

In Buenos Aires, the urban composition features vertical terminal elements, the parallel skyscrapers and the mountain chain. In Montevideo, the terminal elements undergo figural inversion: Palacio Salvo resembles a giraffe or an obelisk over a box; the T-shaped business core uses the same figure upside down. Rio has the business core and a mountain culminating one inhabitable viaduct. With the business core as the head of the city, the so-called Plan Voisin for Buenos Aires suggests either halving Ville Contemporaine because of the river, or prefiguring the Ville Radieuse. The Algiers plan illustrates the new ideal scheme, all components able to develop individually. ${ }^{15}$ But the new does not render the old obsolete. It is simply added to the repertory, applying to all cities that are ports. São Paulo's downtown remains at the heart of the city, as in the Ville Contemporaine.

The sequence is one of topological transformations. Unconcerned with shape or extension, already a major branch of mathematics in the 1920s, topology makes no distinction between curves and straight lines. The rédents that bridge streets in the ideal schemes are topologically identical to the straight rulers and curvilinear ribbons rising as inhabitable viaducts in Brazil and Algeria. Pleated, straight or bent slab buildings, they can be transformed into each other without cutting or tearing, and so do the surfaces making up the typology of sites earlier described. Including the ideal schemes, all the designs are variations on a cruciform structure, except for Montevideo's straight design. The Ville Radieuse is a kind of Lorraine cross with multiple arms. The Ville Contemporaine is both cruciform and $\mathrm{X}$-shaped; given its diagonals, it features both a straight and a rotated Greek cross. Other than a handwritten $\mathrm{X}$ distorting a rotated Greek cross, the Rio inhabitable viaducts may be seen as superposed back-to-back C's, which could be taken apart and pleated or straightened defining parallel strips of slab buildings, thus reinforcing the link between practical applications and unitary principle.

\footnotetext{
${ }^{13}$ Antoine Picon. "Les projets d'Alger et la dimension de l'infrastructure." In Fondation Le Corbusier. Le Corbusier: visions d'Alger (Paris: Editions de la Villette, 2012), pp. 131-145.

${ }^{14}$ Le Corbusier. La ville radieuse, p. 247.

15 Mary McLeod. "Le Corbusier and Algiers." Oppositions 19/20. (Winter-Spring 1980), pp. 55-85. See also Zeynep Çelik. Urban Forms and Colonial Confrontations: Algiers Under French Rule. (Berkeley: University of California Press, 1997), pp. 13-58.
} 
Topological transformations might have started in Montevideo after condensing the multiple towers of Buenos Aires into a single tower, by shortening one arm of that Greek cross until it became a T-shaped Tau cross, and then turning the single tower upside down. The condensation might have been triggered by the small size and greater topographical irregularity of the city, along with the correspondence between the promontory and the boxy base designed for the Buenos Aires towers given not only the different levels of the port and the city, but also the width of the port area, as well as the correspondence between the ridge and the avenue punctuated by the singular figure of Palacio Salvo. Inverting the young skyscraper ensued. Rooftops became parking streets, open to low-speed vehicular traffic. The seascraper was born. By shortening the branch arms, the seascraper roof became one with the avenue. An increase in height, extension, and speed limits on hilly ground followed. The earthscraper was born, a true inhabitable viaduct.

The duplication and intersection of inhabitable viaducts in São Paulo re-enacted a foundational gesture, the horizontal lines at their top counterpointing the sinuous lines at their bottom. The next step was a further increase in height and some bending in Rio, alluding to the Buenos Aires coastal boulevard in the process. The buildable area of Rio is flat ground, and the horizontal lines of the inhabitable viaducts at their bottom and top counterpointed the irregular profile of the surrounding mountains. Bending the buildings adjusted them to the irregular footprint of the mountains. Algiers features slopes with mountains in the backdrop. The inhabitable viaducts bent following the contours or straddled the slopes. Rio- and São Paulo-type earthscrapers accompany a variant of Montevideo-type earthscrapers with curvilinear parking streets at their top, in turn topped by skyscrapers.

Le Corbusier reacted to the Carioca and Algerian sites with the right amounts of contrast and similarity. If domination of the surrounding mountains was impossible, total subordination was avoided. But domination was the obvious choice in flat Paris, or Buenos Aires- whose relationship with the Andes was ideal rather than perceptual, and a reasonable strategy in São Paulo- whose hills were not of striking height. Subordination suited the Montevideo situation- where Palacio Salvo had come first ${ }^{16}$. Architecture reigns in business-minded, tough, workaholic São Paulo and Buenos Aires. Nature shines in beautiful, playful Rio, "a resort", and "charming, tiny" Montevideo. ${ }^{17}$ Architecture and nature recast each other in Algiers. The practical applications were both sitespecific and generalizable, adding to a typology of solutions. While the existing circulation network was tacitly accepted in Buenos Aires and Montevideo, its redefinition was a major problem in São Paulo, Rio and Algiers, providing conceptual and physical grounds for the idea of the inhabitable viaduct. The geometric order of columns anchors the freedom of walls between floor slabs in Le Corbusier's Four Compositions ${ }^{18}$, showing alternatives offered by the standard Dom-ino structure. In Ville Contemporaine, the geometric order of roads anchors the freedom of constant height rédents, strips of pleated slab buildings bridging a directional, hierarchical grid of collector streets, arterial thoroughfares and intercity freeways. The inhabitable viaduct conflated architectural and urban ordering devices. It mixed the primary axes and/or loops of urban circulation with straight or curved slab buildings that were topologically equivalent to rédents bridging existing streets and landscape. In its own way, it is as much an ideal scheme as the Ville Contemporaine or the Ville Radieuse.

\footnotetext{
${ }^{16}$ The Architectural History Foundation; Fondation Le Corbusier. (Eds.) Le Corbusier Sketchbooks - Vol. 1, 1914-1948. (New York: The MIT Press, 1981), B4 drawing 238.

${ }^{17}$ Le Corbusier, Précisions, p. 244.

${ }^{18}$ Willy Boesiger and Oscar Stonorov. Le Corbusier et Pierre Jeanneret. Oeuvre complète de 1910-1929, 14th ed, (Zurich: Editions d'Architecture/ Edition Girsberger), p. 189.
} 


\section{Precedents}

Le Corbusier did not shun making comparisons that doubled as statements of inspiration, as the béguinage example shows. If he maligned the styles rendered obsolete by the machine age in the first Buenos Aires conference, he quickly added, "people label me today a revolutionary, but I have not had other master than the past, other discipline than the study of the past."19 Despite broken alignments, the exaggerated building continuity of the rédents paved the way for the inhabitable viaduct. Rédents were indebted to Eugène Hénard, who first proposed broken alignments in boulevards à redans (1903). Inhabitable viaducts are therefore indirectly relatable to Parisian hôtels particuliers, Versailles, phalanstères, or Auguste Perret's apartment building at rue Franklin (1902-1904). Le Corbusier preferred to rhapsodize when presenting the São Paulo earthscrapers to his public:

"What bigger Segovia aqueduct, what giant Pont du Gard! Is there anything more elegant than the pure line of a viaduct in an uneven terrain, and more diverse than their substructures piercing the undulations to meet the ground?" 20

Earthscrapers were wittily compared to water-bringing devices in the only city in the sequence that was not a port. The comparison reinforced the allusions to Roman urbanism, and hence to the foundational character of inhabitable viaducts. Le Corbusier had published images of the two aqueducts in the same page as Gustave Eiffel's 1545 meters long Cubzac Bridge (1883) and the Marseille Transporter Bridge (1905), whose 239 meters long movable platform rose 50 meters. ${ }^{21}$ FIG. 10 These benchmarks went unmentioned, as did another steel structure, Eiffel's 554 meters long, 122 meters high Garabit Bridge (1888), the opening image of Vers une architecture. Otherwise, Le Corbusier recalled neither massive and straight railway viaducts like the reinforced concrete, 152 meters long, 65 meters high Day (1925) in Switzerland, and the brick masonry, 574 meters long, 78 meters high Goltzschtal (1851) in Germany, nor massive and curvilinear railway viaducts in limestone masonry like the 136 meters long, 65 meters high Landwasser (1902), and the spiral 110 meters long Brusio (1908), both Swiss-made.

Curvilinear inhabitable viaducts have been likened to mid-eighteenth-century one-sided streets such as the serpentine, 500 meters long John Palmer's Lansdown Crescent at Bath, ${ }^{22}$ and straight inhabitable viaducts could have been likened to early nineteenth-century one-sided streets such as Charles Percier and Pierre Fontaine's Rue de Rivoli extending its arcades for 1100 meters in Paris. More to the point, the Rio and Algiers designs suggest the crossing of crescents with scenic American parkways (such as Long Island) ${ }^{23}$ or a touristic road from Milan to Varese (Autostrada dei Laghi), whereas the São Paulo proposals combine a racing track in suburban Berlin (AVUS) with Parisian croisées. Besides the 800 meters long Fiat Lingotto factory, hybrid objects considered as precedents include medieval inhabited bridges or Edgar Chambles's 1910 Roadtown also involve a standard lasting structure designed to withstand public vehicular mobility mixed with an ordinary, transient infill intended for private occupation and slower rhythms. ${ }^{24}$ An offspring of that factory must have been at least

\footnotetext{
${ }^{19}$ Le Corbusier. Précisions, p. 34.

${ }^{20}$ Le Corbusier. Précisions, p. 242.

${ }^{21}$ Le Corbusier. Une maison - un palais. À la recherche d'une unité architecturale. (Paris: Crès, 1928), p. 20.

${ }^{22}$ Siegfried Giedion. Space, time and architecture. The growth of a new tradition. (Cambridge, Mass.: The Harvard University Press, 1941), pp. 81-84, 91-94.

${ }^{23}$ Carlos Eduardo Comas. "Le Corbusier and the Brazilian Landscape", in Jean-Louis Cohen and Barry Bergdoll (eds.). Le Corbusier: an Atlas of Modern Landscapes (New York: The Museum of Modern Art, 2013), pp. 324-331.

${ }^{24}$ Stanislaus von Moos. Le Corbusier. Elements of a synthesis. ${ }^{\text {nd }}$. Ed. (Rotterdam: 010 Publishers 2009), pp. 198-99.
} 
mentioned to Le Corbusier in Buenos Aires. Close to his hostess Victoria Ocampo's property, Palanti's Palacio Chrysler (1927-1928) was a car dealership and repair workshop with an oval test track as rooftop, less of a wedding cake than Palacio Barolo or Salvo. ${ }^{25}$ FIG. 11

Le Corbusier noted himself in Algiers that "the viaduct level 100, it is built at the port!"26 FIGS. 12, 13 CharlesFrédéric Chassériau had designed the 1500 meters long Arcades des Anglais (1860-66) as a kind of engaged viaduct, or hollow retaining wall fronting the sea. They featured a giant order and were roofed by Boulevard de la République and the ramps and staircases leading to it. Shops were inserted at the level of the port, and dwelling for fishermen served by galleries at the intermediary level. Le Corbusier's note was not without reservations, as he added, "nothing was conceived with particular efficiency for the housing of families." Le Corbusier's inhabitable viaducts were disengaged, bridge-like, so he could say he was correcting the deficiencies of the Arcades des Anglais, and providing an optimal condition for housing. Next to the sketch of the Arcades in La Ville Radieuse, he placed a photo of the Lingotto factory, which he claimed he had forgotten prior to the 1934 visit, so that the idea of a roof road had come to him spontaneously. ${ }^{27}$ Le Corbusier's reference to the Arcades confirms that he recognized the power of the proper, meaningful precedent as a tool for understanding and persuasion, as well as an object of topological transformations inasmuch as the Arcades were straight, and the Algerian inhabitable viaducts curvilinear. His claim of spontaneity would be more convincing if there were no Palacio Chrysler to remind him of the Lingotto factory. But he might be telling the truth from a certain point of view, as topological transformations may be undertaken subliminally.

\section{Monumental issues}

Le Corbusier invoked no precedent whatsoever for Rio, not even its eighteenth-century Lapa Aqueduct, and at first sight he likened urbanizing the city to filling the tub of the Danaides, an eternal punishment ${ }^{28}$. Flights increased his grasp of the Carioca and Algerian sites. ${ }^{29}$ Allowing for bird's eye views, they confirmed rather than revealed that the roof plan was a fifth façade. Surveys had been done before the airplane was invented, maps drawn, and models made. He did not need airplanes to design the 1927 Palace of League of Nations in Geneva with the Alps in the background. He commented:

"We have led the development of our buildings towards a single, smooth and pure horizontal crowning, that pure horizontal high up, sometimes profiled against the sky, sometimes giving their measure to the mountains that surpass them, that horizontal was a conclusion of lyrical order. "30

The horizontality of the Rio and Algiers viaducts from the water mattered as much as their curves from the air. Curves were not alien to Le Corbusier's vocabulary. Rio brought about their emphatic application to an urban and bigger scale. Algiers, a similar type of site, amplified it. This sense of the organic was not prompted only by uneven terrain. Aerodynamics was changing the appearances of cars and airplanes, and Aircraft shows that Le

\footnotetext{
${ }^{25}$ For similar comment, Liernur. La red austral, pp. 144-45; Gutierrez, Le Corbusier y el Río de la Plata, p. 47.

${ }^{26}$ The Architectural History Foundation: Fondation Le Corbusier, Le Corbusier Sketchbooks- Vol. 1, 1914-1948. C10, drawing 660.

${ }^{27}$ Le Corbusier. La Ville Radieuse, p. 241.

${ }^{28}$ Le Corbusier. Précisions, p. 244.

${ }^{29}$ Yannis Tsiomis, 'Rio-Alger-Rio, 1929-1936, Transferts'. In Fondation Le Corbusier 2012, Le Corbusier. Visions d'Alger, (Paris: Editions de la Villette: 2012), pp. 84-101. See also Yannis Tsiomis (ed.). Le Corbusier. Rio de Janeiro 1929-1936 (Rio de Janeiro: Centro de Arquitetura e Urbanismo, 1998).

${ }^{30}$ Le Corbusier. Une maison - un palais, pp. 152, 163.
} 
Corbusier was aware of $\mathrm{it}^{31}$. Curved surfaces were replacing the straight surfaces and boxy volumes so emblematic of movement technology in the first half of the 1920s. In the second half of the 1920s the old biplane shape gave way to the streamlined monoplane configuration of the racing seaplanes that won the Schneider Trophy from 1913 to $1931^{32}$. Although not as dramatic, the transformation also showed in cars ${ }^{33}$. The machine was becoming biomorphic, and Le Corbusier had anticipated it by publishing an early image of the "airplane of the future" ${ }^{34}$. FIG. 14

In short, Rio and Algiers brought no fundamental change in Le Corbusier's architecture and urbanism: he just expanded his vocabulary. He reacted to both ideal and actual sites, spectacular and plain landscapes, with a similar monumental impulse, long operative in his work, and duly disapproved by left leaning critics when he first presented Ville Contemporaine. Le Corbusier wanted to build both houses and palaces. He certainly subscribed to Charles Baudelaire's understanding of modernity as "the fleeting, the transient, the contingent, the half of art of which the other half is the eternal and the immovable" ${ }^{, 35}$. Garabit Bridge features again in "Perennité," a chapter of Urbanisme ${ }^{36}$. FIG. 15 Moreover, despite his diatribes against academicism, Le Corbusier made full and inventive use of the whole Beaux-Arts mental equipment. ${ }^{37}$ His entry for the Palace of the League of Nations and subsequent project for a Mundaneum had been chastised by El Lissistky and Karel Teige under those terms ${ }^{38}$.

The designs for São Paulo, Rio or Algiers have obvious monumental qualities. Formal simplicity, size, visibility at distant range, symmetry and axiality make the overall composition and its elements highly memorable. The contrast with irregular, picturesque, and lower urban fabric would be striking: differences in scale and figural attributes like isolation and dominance would make the overall composition and its elements look exceptional. Although the durability of unbuilt projects cannot be gauged, Le Corbusier acknowledged the different potential duration of different urban or architectural elements, and emphasized accordingly the role of the standard structure and the circulation grid in his designs. He understood that ordering devices were lasting devices, and vice-versa ${ }^{39}$. Order, he insinuated, can turn a house into a palace. Le Corbusier adhered to height uniformity as strict as that regulating Haussmann's Paris. The picturesque and the irregular might find another place in the artificial sites at the floor slabs, and create a kind of latter-day Diocletian's Palace.

References are an aid regarding representation, and Le Corbusier understood how essential representation was for the memorability of built or unbuilt designs, in drawings, models, photographs, and print. Most of his work has endured in paper. Victor Hugo prophesized: the book would kill the cathedral as the privileged means of social bonding. ${ }^{40}$ Yet drawings or prints promoted architecture even in medieval times. Figural resemblances and associations mattered: the image of the cruciform church plan reinforced in bi-dimensional terms the building's

\footnotetext{
${ }^{31}$ Le Corbusier. Aircraft (London: The Studio, 1935).

${ }^{32}$ John David Anderson, Jr. A history of aerodynamics and its impact on flying machines. (Cambridge: Cambridge University Press, 1997), pp. 355-358.

${ }^{33}$ Antonio Amado. Voiture minimum. Le Corbusier and the automobile. (Cambridge, Mass.: The MIT Pres, 2011).

${ }^{34}$ Le Corbusier. Vers une architecture, p. 239: cover of Louis Charles Bréguet. L'aviation d'hier et de demain (Paris: Draeger 1921).

${ }^{35}$ Charles Baudelaire. "La modernité", a chapter of Le peintre de la vie moderne (1863).

${ }^{36}$ Le Corbusier. Urbanisme, pp. 41-50.

${ }^{37}$ Reyner Banham. Theory and Design in the first machine age. (London: The Architectural Press, 1960), pp. 14-22. Colin Rowe. The architecture of good intentions. (London: Academy Editions, 1994), pp. 101-102.

${ }^{38}$ Le Corbusier. Précisions, p. 225

${ }^{39}$ Le Corbusier was anticipating the Japanese Metabolist thinking and ideas on mass housing of the 1960s, not to mention his own Unité d'Habitation in Marseille (1945-52).

${ }^{40}$ Victor Hugo. "Ceci tuera cela", second chapter, fifth book. Notre Dame de Paris (1831).
} 
connection with the Crucifixion. An appropriate evocation adds to the intelligibility of the design. The cross recalls Roman urbanism in São Paulo, the pairs of divergent curves at the opposite sides of a straight stem suggest a dancer in Rio, bent rédents in Algiers relate both to the anatomy of Arab women and Arabic calligraphy ${ }^{41}$.

Aqueducts were particularly apt references given their persistence through centuries and their suggestive massiveness. It was not difficult to imagine their bays filled with diverse and changeable dwellings, standing on "artificial sites" provided by floor slabs, and standing for ephemerality in comparison to the timelessness of the structure. The contrast between the Segovia Aqueduct and more recent buildings in its vicinity provided additional information for the public. They were of the adequate height too: Segovia was 28 meters high and 813 meters long, Pont du Gard was 48,8 meters high and 275 meters long. Viaducts are bridge-like structures, and the bridges Le Corbusier published admiringly would give a better idea of the proposed horizontal lines in Rio, but Garabit was too light against the landscape or the Marseille transporter high up in the sky too light over the roofs, and they lacked substance. The Arcades des Anglais was a better reference for functional hybridism, but not tall enough, and unknown to Le Corbusier before his 1931 trip to Algiers.

Le Corbusier made formal qualities suggest distinction of purpose. Prominence of place, verticality and cruciform plan combine to emphasize the real and symbolical importance of a new business core. The very idea of a vertical business core was not that old: Rockefeller Center would not be completed until 1939. An intersection, it orders the São Paulo downtown. It sits on artificial headland in Rio. It stands as an artificial cliff close to the water in Algiers. Le Corbusier presents business cores as towering bastions. Inhabitable viaducts are ramparts, condensing three basic objectives into a single element: adequate provision for fast automobile traffic connecting city and territory, adequate provision for high-density housing, and minimum occupation and disturbance of the ground. Megastructures of imposing length, they are also backdrops against which the business core is deployed, along with cultural facilities, historic monuments, parks, a sizable portion of the existing urban fabric, and natural topography. New building not only straddles green fields as in the ideal schemes, but also fields filled with the remains of bygone eras and the recent past. An example is the volume of the Municipal Theater recognizable in the three published drawings of the São Paulo proposal. Urban renewal was not predicated on razing all but the outstanding historical monuments of a district as in Plan Voisin. Razing was one strategy among others for dealing with underused, overcrowded or obsolete areas. Business, housing and traffic were the key urban problems. As in Paris, Buenos Aires and Montevideo, there was no shortage of cultural facilities in São Paulo, Rio and Algiers. Although the new business cores and inhabitable viaducts would alter these cities, they would not cancel their polycentrism, they would add to their multiple foci. These were not villages where public spaces were restricted to the main street and the city square.

The hybridism of the inhabitable viaduct had further resonances. The modern viaduct, the result of an engineering esthetics, would rather look like Garabit than a Roman aqueduct. But for Le Corbusier, engineers made tools, and in time tools are discarded, like the old locomotive that is "thrown for scrap" ${ }^{42}$. He did not object to bridges, dams, tunnels, viaducts, and other big structures of public utility being called in French ouvrages d'art since the late nineteenth century, made to last even if lacy. At the same time, he claimed that the difference between the house and the palace was one of degree, but he recognized that the house belongs to the private realm, and the palace to the public realm: "a palace is a house that impresses by the dignity of its aspect ${ }^{\prime 43}$. The modern viaduct lacked gravitas but had public status, and could endow ordinary housing with a

\footnotetext{
${ }^{41}$ Kenneth Frampton, “Mariage des contours.” Oppositions 19/20, p. 87.

${ }^{42}$ Le Corbusier. Vers une architecture, p. 5.

${ }^{43}$ Le Corbusier. Une maison - un palais, p. 52.
} 
public aura. In turn, ordinary, ephemeral housing would paradoxically lend substance, solidity and stability to the transparent but enduring viaduct dedicated to speed.

"A city made for speed is a city made for success" $"$, said Le Corbusier, but his emphasis on mobility was restricted to cars, buses and trucks: "the tramway has no longer rights in the heart of the modern city" published Garabit Bridge at least thrice, never mentioning that it was a railway viaduct. Rio, São Paulo and Algiers were cities without subways. He thought that the inhabitable viaduct would obviate the need for a subway in Algiers. Reference to rail transportation in his texts is hasty. As seen, he was at best ambivalent about the role of railway viaducts in the genesis of his inhabitable viaduct. Rails were nineteenth-century, while the automobile and the airplane were contemporary. Freeways in the 1920s were a novelty. Autobahnen, autostradas and carreteras only became conspicuous after 1930, in countries not as rail-rich as England or France. For Le Corbusier,

"The civilization of the road will re-establish the harmonious and regular relations between town and country, relations broken by the railway that, working contrariwise, had emptied the country in favor of the town and had drawn men away from nature, their natural milieu. "46

Motorized mobility was more than a means of transport. Le Corbusier celebrated the pleasure the inhabitable viaduct would afford for the driver and passengers alike, confined high up in the sky, conscious of acceleration, propulsion, gravity and of the landscape unfolding before them. Curves would augment the exhilaration in Rio and Algiers, but there, as in São Paulo, the experience would resemble racing instead of cruising. Exhilaration was to rely upon the restraining limits of guardrails, the tokens of bondage in the controlled access public space of the freeway. Freedom characterized the opposite end of the urban movement hierarchy. Le Corbusier despised the pedestrian flânerie in the Grands Boulevards described by Baudelaire, although allotting space for it at the feet of the great skyscrapers in Ville Contemporaine's business core. He preferred casual encounters happening amid greenery. He did not rule out completely the frontal alignments that characterize the hated, congested multifunctional corridor street of the railroad city, as well as the square: both re-appear sometimes in the Ville Radieuse superblocks as the chance meeting of rédents, but their width is grossly expanded, as if fearing enclosure by architecture itself. And the lone pedestrian looks pitiful in the drawing illustrating an Algiers rooftop freeway.

\section{Crashes}

The inhabitable viaducts were alternatives to contemporary plans for São Paulo (by Prestes Maia), Rio (by Alfred-Donat Agache) and Algiers (by Henri Prost, René Danger and Maurice Rotival). But Le Corbusier shared many ideas with his opponents from the Société Française des Urbanistes (of which Hénard had been a founder). Diagnostics were often similar, and solutions too. Le Corbusier did not invent zoning, street hierarchy, grade separation between pedestrians and cars, urban parks, differentiation of residential neighborhoods by income level, or razing slums, for instance. Le Corbusier built upon Rotival's ideas for Algiers ${ }^{47}$, which included skyscrapers au Quartier de la Marine, coastal boulevards at different levels atop parking garages, car elevators and a viaduct connecting Boulevard de la République with a proposed boulevard 100 meters above sea level.

\footnotetext{
${ }^{44}$ Le Corbusier. Urbanisme, p. 190.

${ }^{45}$ Le Corbusier. Urbanisme, p. 162.

${ }^{46}$ Le Corbusier. "Les besoins collectifs et le génie civil." In Anatole de Monzie, Pierre Abraham (eds.). L'Encyclopédie Française, Tome XVI (Paris: Societé de l’Encyclopédie Française, 1935).

${ }^{47}$ Maurice Rotival, "Veut-on faire d'Alger une capitale?” Chantiers nord-africains (Jan 1931), pp. 27-37.
} 
FIG. 16 Rotival took New York's Wall Street area as an example. Preservation of the Casbah was then French policy, and both Rotival and Le Corbusier agreed with it. Still, in comparison, Le Corbusier's enthusiasm for both the freeway and greenery verged on fetish, his publicly controlled automotive city plans matched only by their polar opposite, Frank Lloyd Wright's contemporary Broadacre City (1932).

In its day, the inhabitable viaduct did not interest Brazilian and Algerian decision-makers. Its practicality was open to question in engineering, financial and political terms. The hybrid solution might look like synthesis for his author. Far from being worked out in all details, it did not conform to either engineering or development logic. Many people, irrespectively of income bracket, might find it psychologically disturbing. Workers in Algiers might accept a road over their heads, since their dwellings would be close to working quarters, and fourteen square meters per person was a rather decent provision, but low-income housing was not a priority for either government or private enterprise in any of these cities. The upper classes preferred villas to apartments. Le Corbusier's appeal to authority fueled charges of authoritarianism. ${ }^{48}$

Authoritarian has two meanings: one is aristocratic (favoring, denoting, or relating to government by a small elite with wide powers); the other, behavioral (telling other people what to do in a peremptory or arrogant manner). Authority is basically either the power to make decisions, or the power to influence and persuade resulting from knowledge and experience. After receiving Plan Obus, Mayor Charles Brunel replied to Le Corbusier, ${ }^{49}$ saying it was too costly, and would lead to the complete destruction over time of the existing city. To implement the Plan, a French mayor would need dictator powers with the property, and even lives of his subjects. Le Corbusier did not take human needs into account. Apartments were awful, and small, and no one would want to live in them, given the possibility of a house in the hills. No need to work close to dwelling.

Le Corbusier might believe and behave in authoritarian ways, but he had no authority other than his expertise, and his authority as an expert was lost on the political authority of the mayor. Whether as apolitical or affiliated professional, Le Corbusier dazzled without persuading, and dominated without convincing. ${ }^{50}$ The mayor might reasonably think that Le Corbusier's plan was too costly, and would have no political support, as landowners would oppose it, rejecting low-income public housing and going for suburbanization; fears of destruction might be justified, but could the mayor stop the growth of Algiers, and piecemeal destruction of the present city?

Nothing in principle prevented democracies to build large pieces of public urban infrastructure and low-income high-density public housing. A large aggregate of small-scale transformations over time disrupts cities as much as any large-scale intervention, including subway construction going on in Paris, London and New York. Le Corbusier was not alone in criticizing the disorderly and fragmentary expansion of cities through lot-by-lot vertical redevelopment and suburbanization, or in advocating planning instead of laissez-faire. But he posited unconventional change, reacting to the problems and opportunities of the modern city first and foremost as visionary architect. The inhabitable viaduct transposed the Fiat Lingotto factory for the sake of reconciling increased physical mobility with dwelling and landscape, recreating the physical immobility of the land in its structure along with an immemorial, elementary and enduring urban layout with its artificial sites, interior streets, and transient houses. It also celebrated, in the Algerian coast, the feasibility, from an architectural standpoint, of extending to the many environmental advantages hitherto reserved to the few. Low-income

\footnotetext{
${ }^{48}$ Jean-Pierre Giordani. "Le Plan-Obus 1932-3: du sublime aux réalités”. In Fondation Le Corbusier 2012, Le Corbusier. Visions d'Alger, pp. 102-129; Simone Brott. "Architecture et Révolution: Le Corbusier and the Fascist Revolution." Thresholds 41 (Spring 2013), pp. 146-157.

${ }^{49}$ Letter from December 26, 1932, apud Mary McLeod, note 16. Oppositions 19/20, pp. 82-83.

${ }^{50}$ Tim Benton. "La rhétorique de la vérité: Le Corbusier à Alger. In Fondation Le Corbusier, Le Corbusier. Visions d'Alger, p. 186.
} 
housing was not only close to the workplace. It enjoyed all too visibly some of the best views in town, comparable to those from the upscale rédents at Fort-l'Empereur. Class differences in the Plan reminded this was not utopia, but a historical possibility depending on public policy. Tellingly, no coastal inhabitable viaduct featured in the second and also unasked for Plan Obus, submitted in 1933. As Le Corbusier well knew, architecture depends upon power. And yet, even granted that architecture is the dependent variable in its relationship with society, to know what is theoretically possible in any field is to allow wider scope for decisions, objectives, choices ${ }^{51}$. For all its flaws, assertive, provocative, monumental, the inhabitable viaduct still frightens, and enlightens.

\footnotetext{
${ }^{51}$ Leslie Martin \& Lionel March. Urban space and structures. (Cambridge: Cambridge University Press, 1972), p. 26.
} 


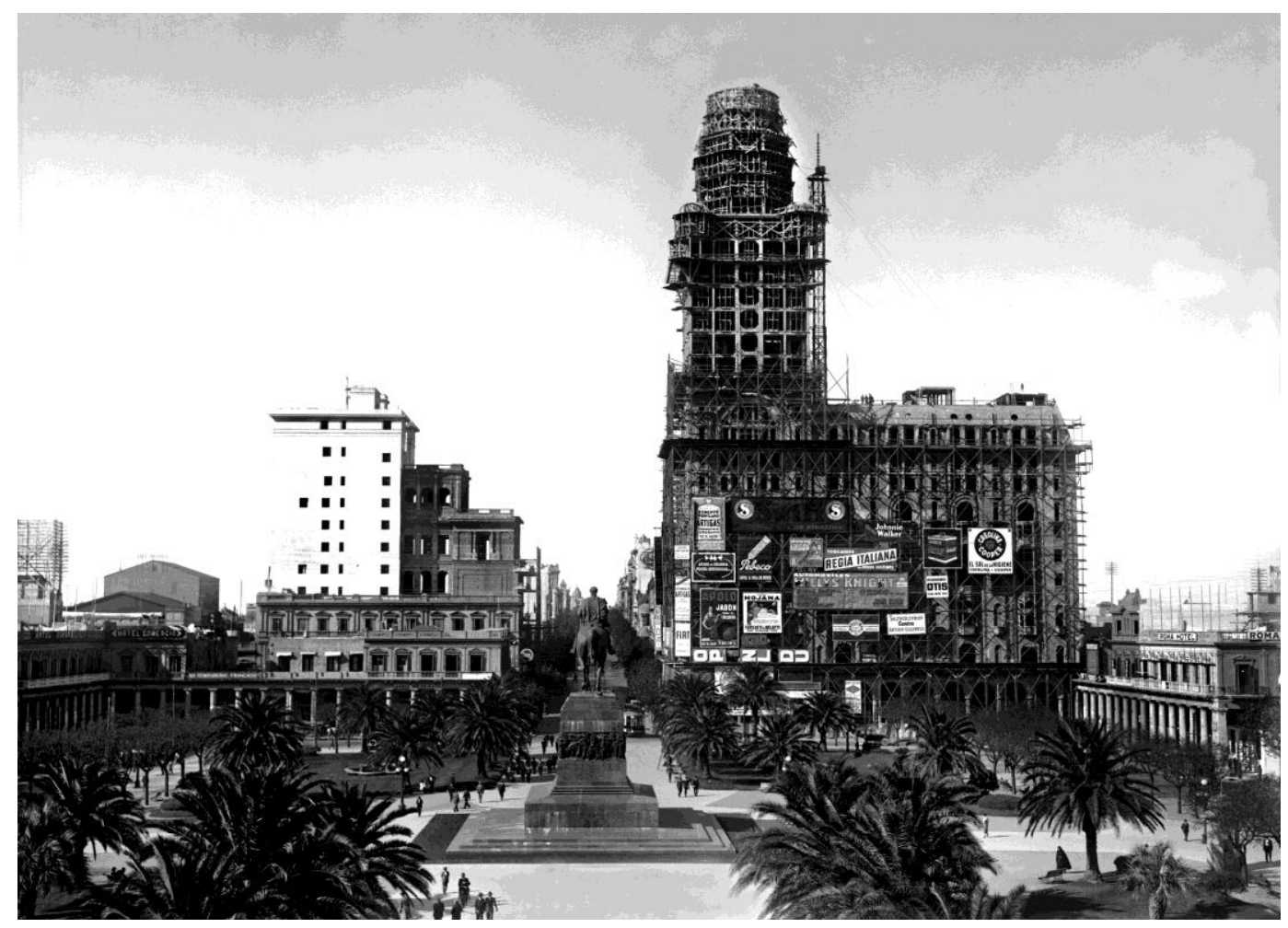

1. Postcard showing Palacio Salvo under construction from Plaza Independencia. 1926.

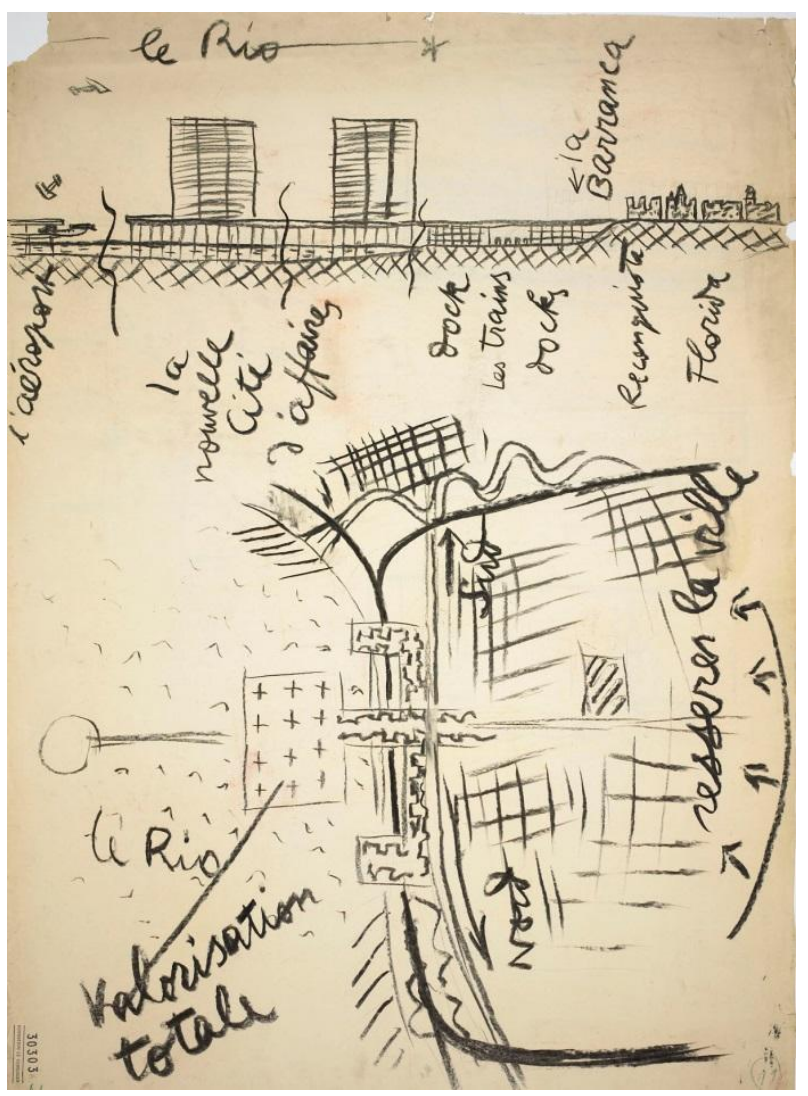

2. Le Corbusier. Plan for Buenos Aires. 1929. From "Précisions sur un état présent de l'architecture et de l'urbanisme“, (Paris: Crès, 1930), p. 206. 


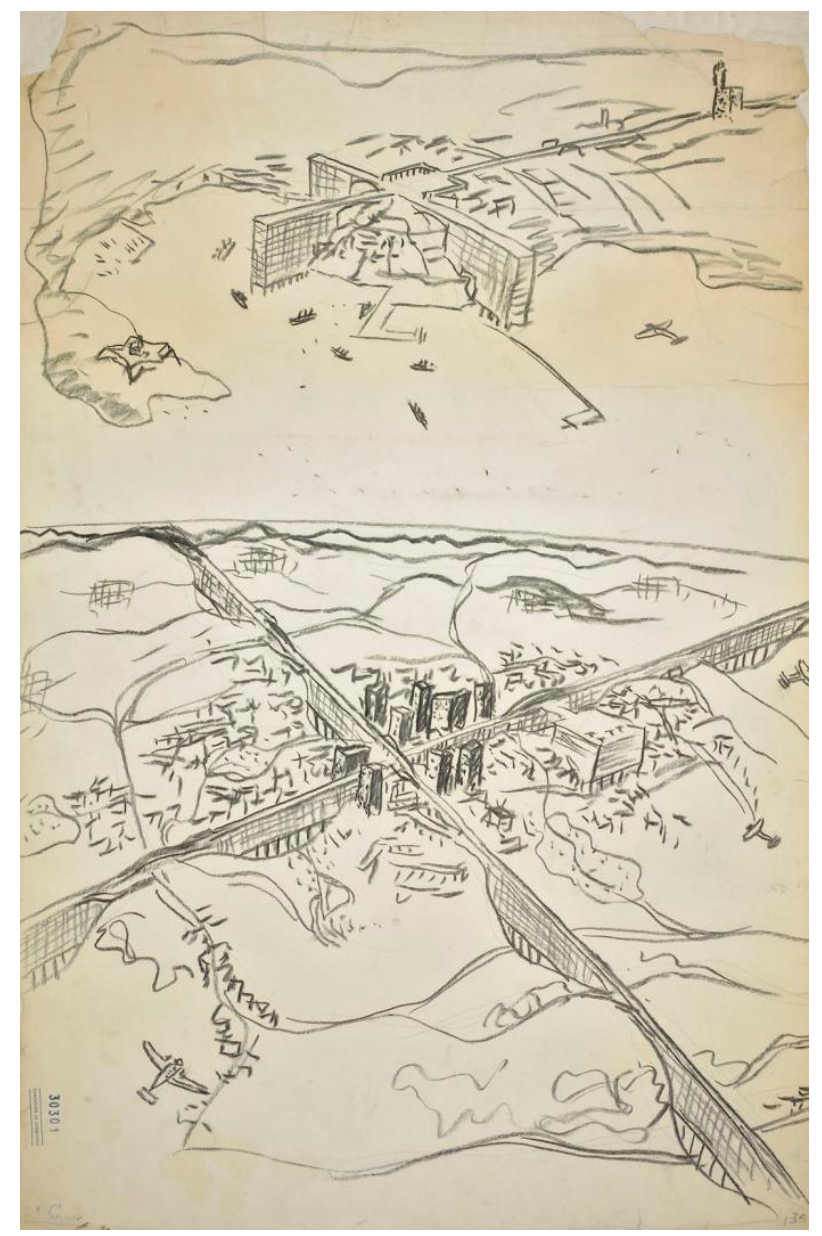

3. Le Corbusier. Plans for Montevideo and São Paulo. 1929. Fondation Le Corbisoer, Paris FLC 30301

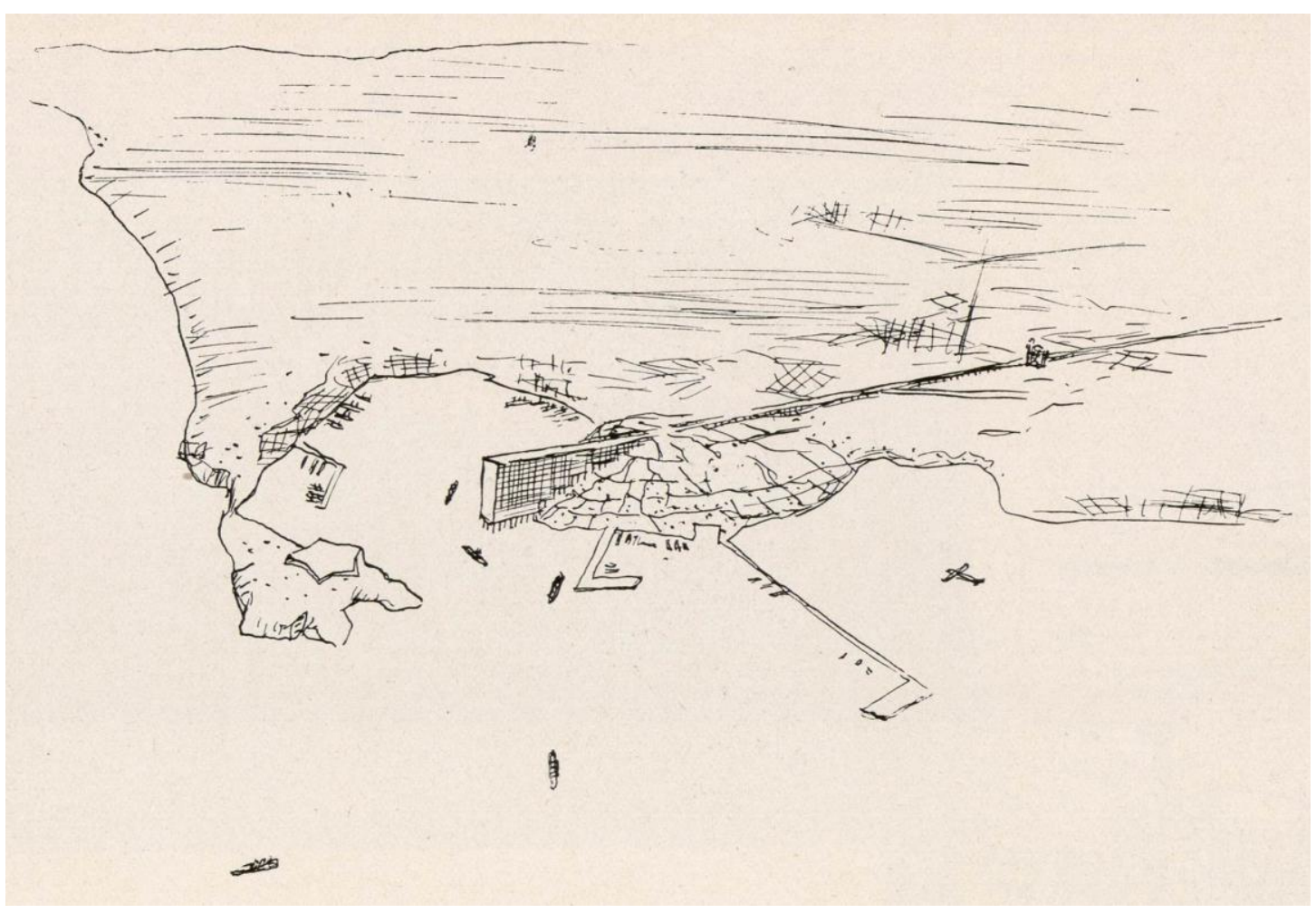

4. Le Corbusier. Plans for Montevideo. 1929. From La Ville Radieuse, p. 222. 


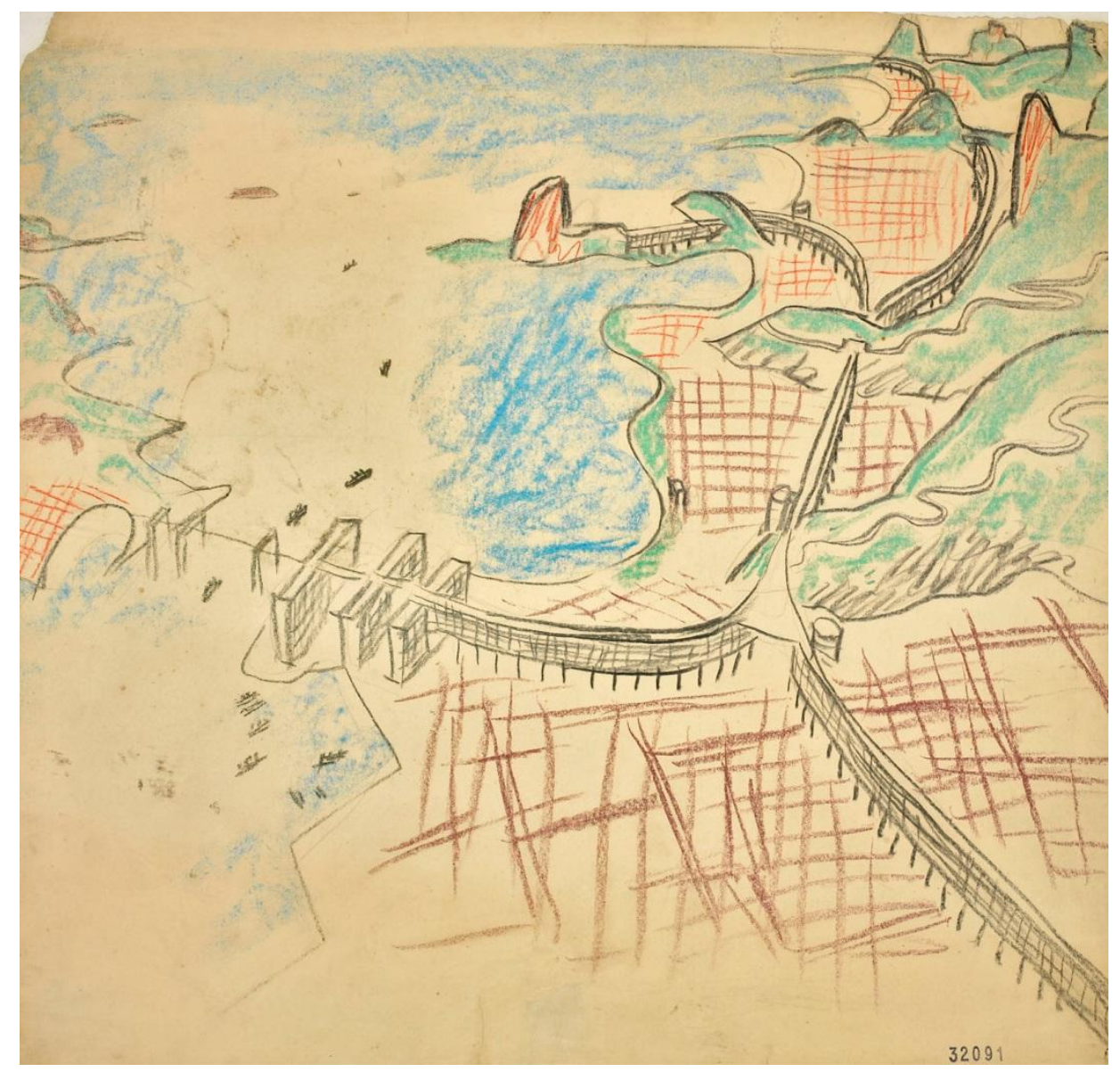

5. Le Corbusier. Plan for Rio de Janeiro. Fondation Le Corbusier, Paris FLC 32091

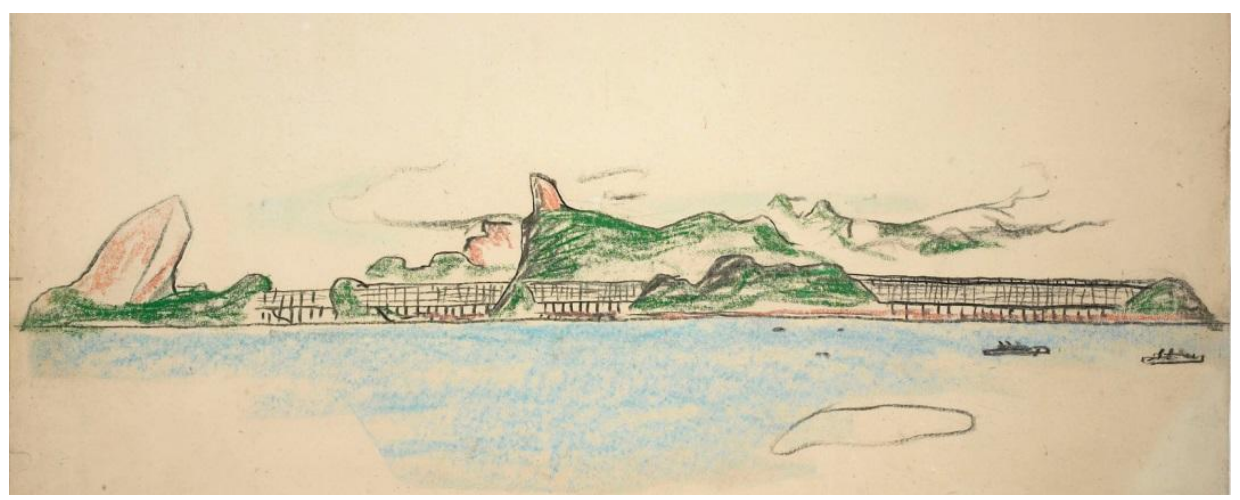

6. Le Corbusier. Plan for Rio de Janeiro. 1929. Fondation Le Corbusier, Paris. FLC 33425

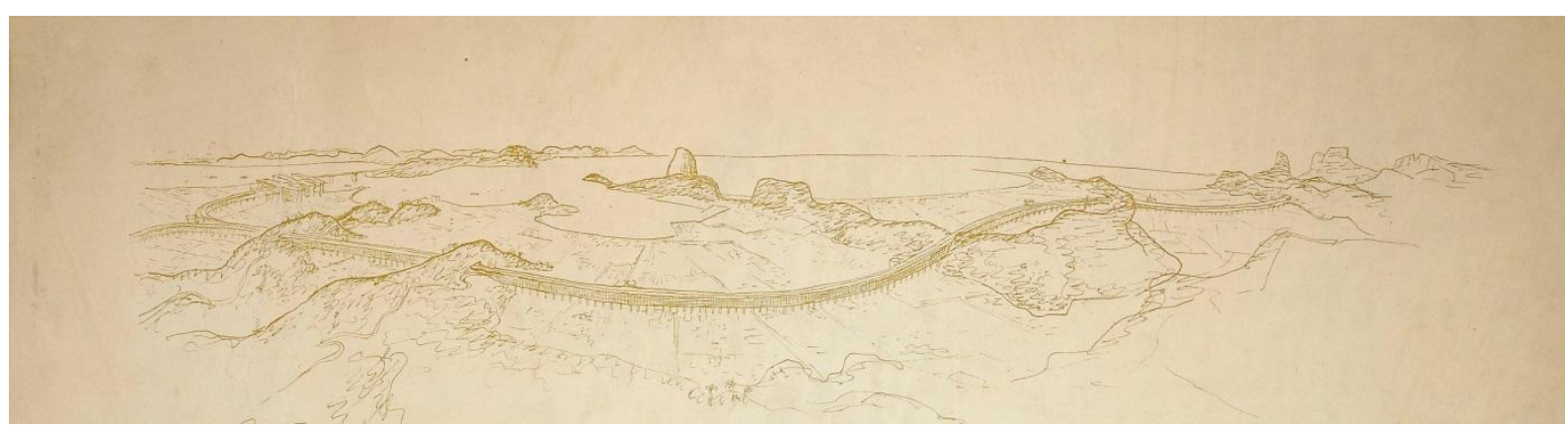

7. Le Corbusier. Variant of plan for Rio de Janeiro. 1930. Fondation Le Corbusier, Paris. FLC 31878 


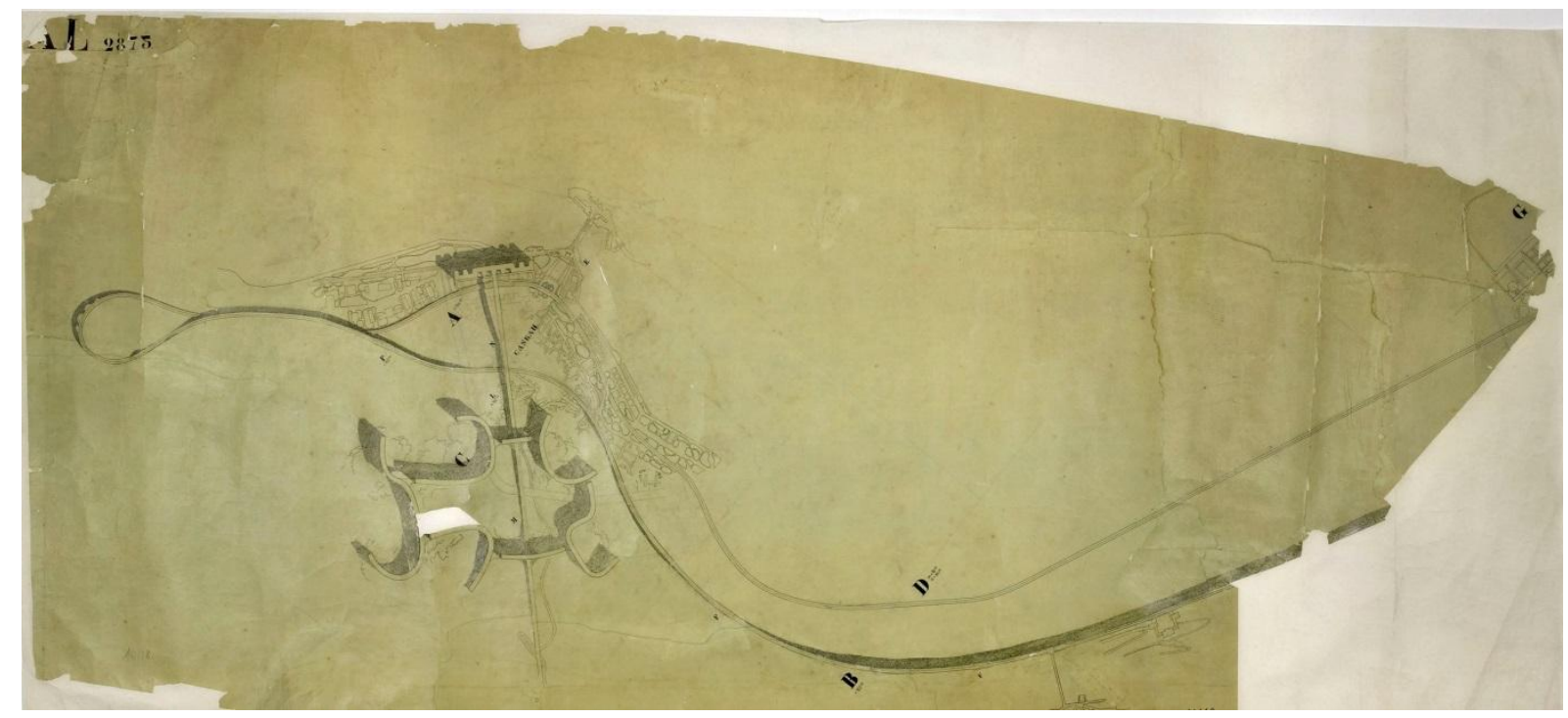

8. Le Corbusier. Plan Obus for Algiers. 1932. Fondation Le Corbusier, Paris. FLC 14118

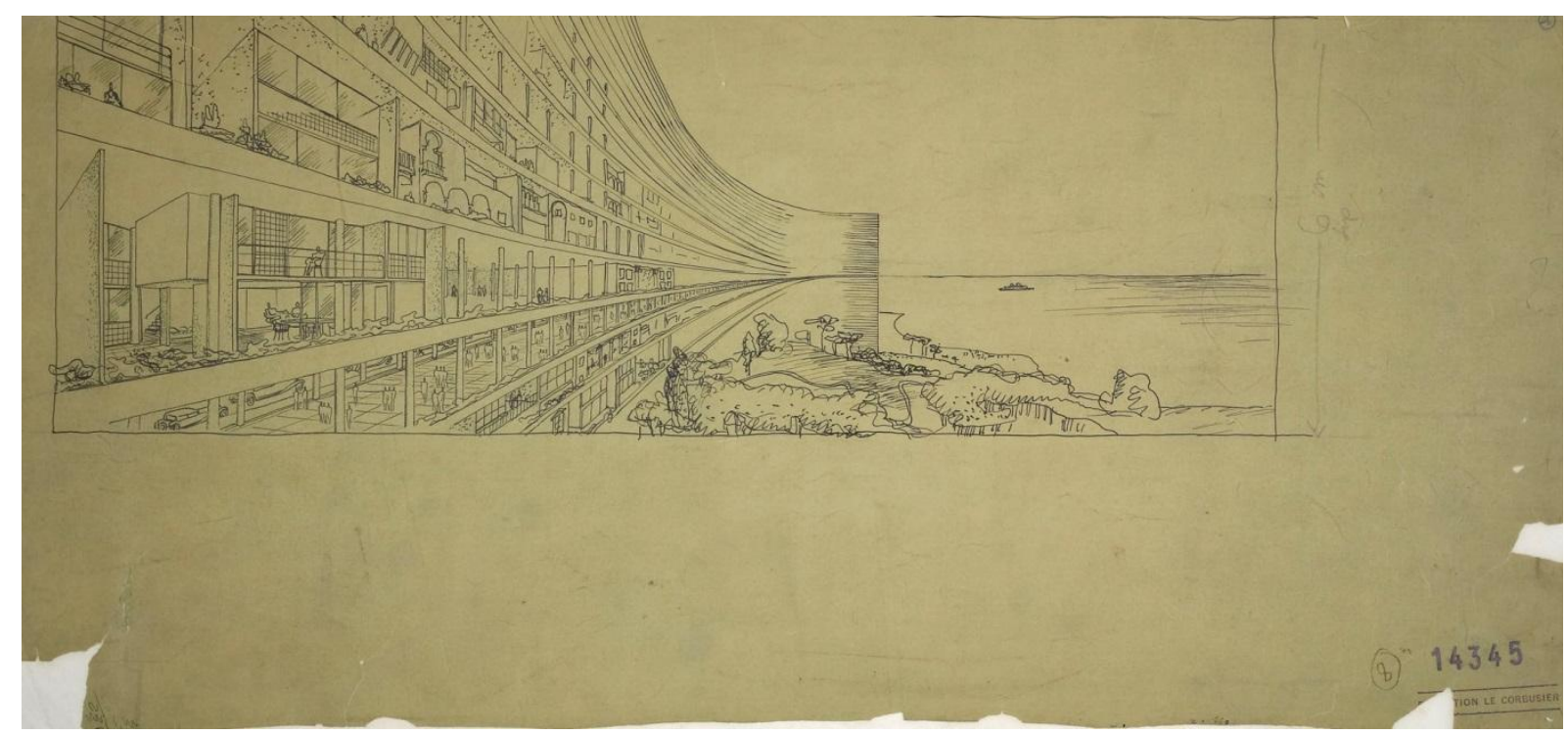

9. Le Corbusier. Plan Obus for Algiers. Perspective. 1932. Fondation Le Corbusier, Paris. FLC 14345 


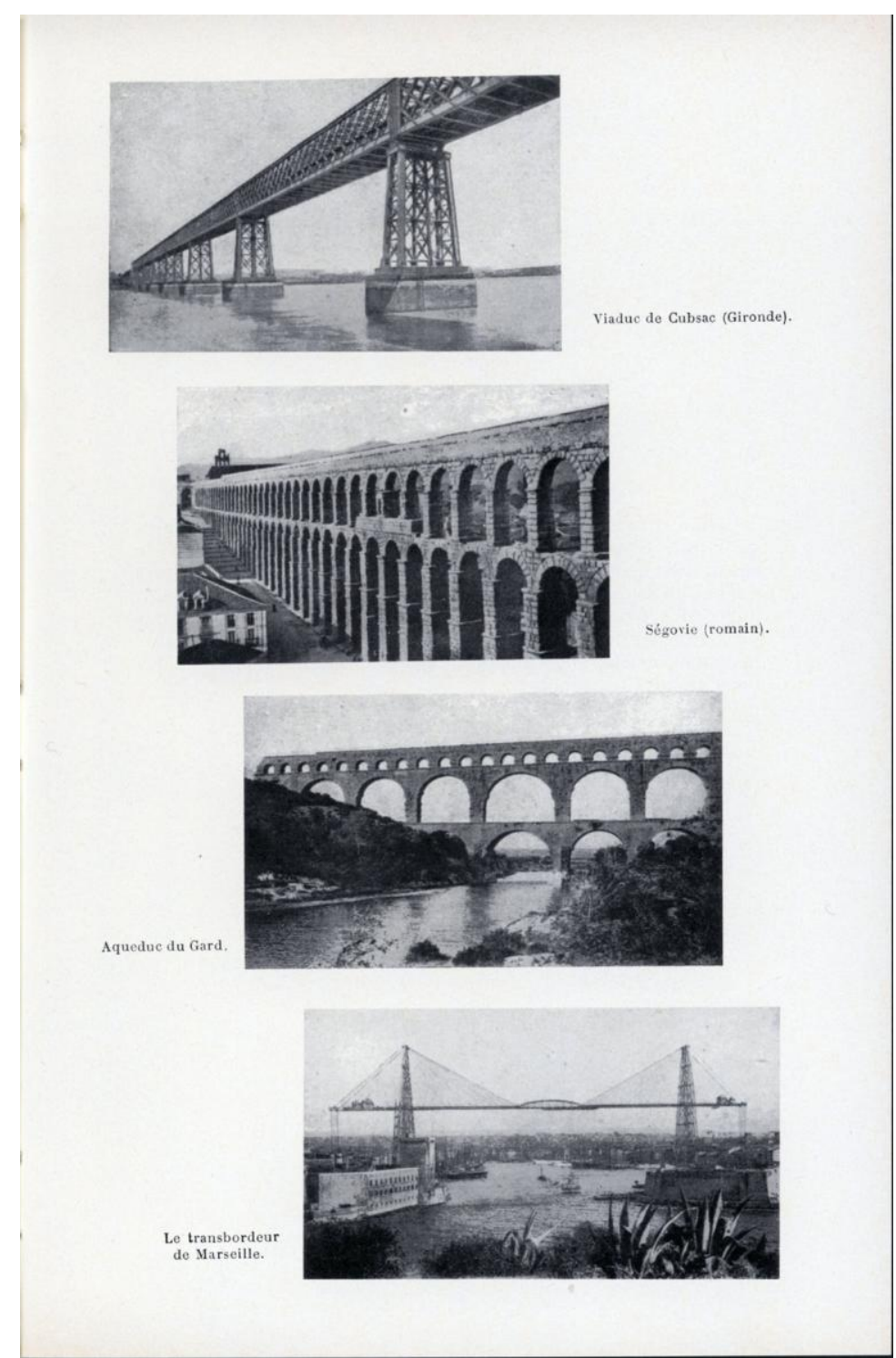

10. Cubzac Viaduct, Segovia Aqueduct, Pont du Gard and Marseille Transporter Bridge. From Le Corbusier, "Une Maison, Un Palais", (Paris: Crès, 1928), p. 21 


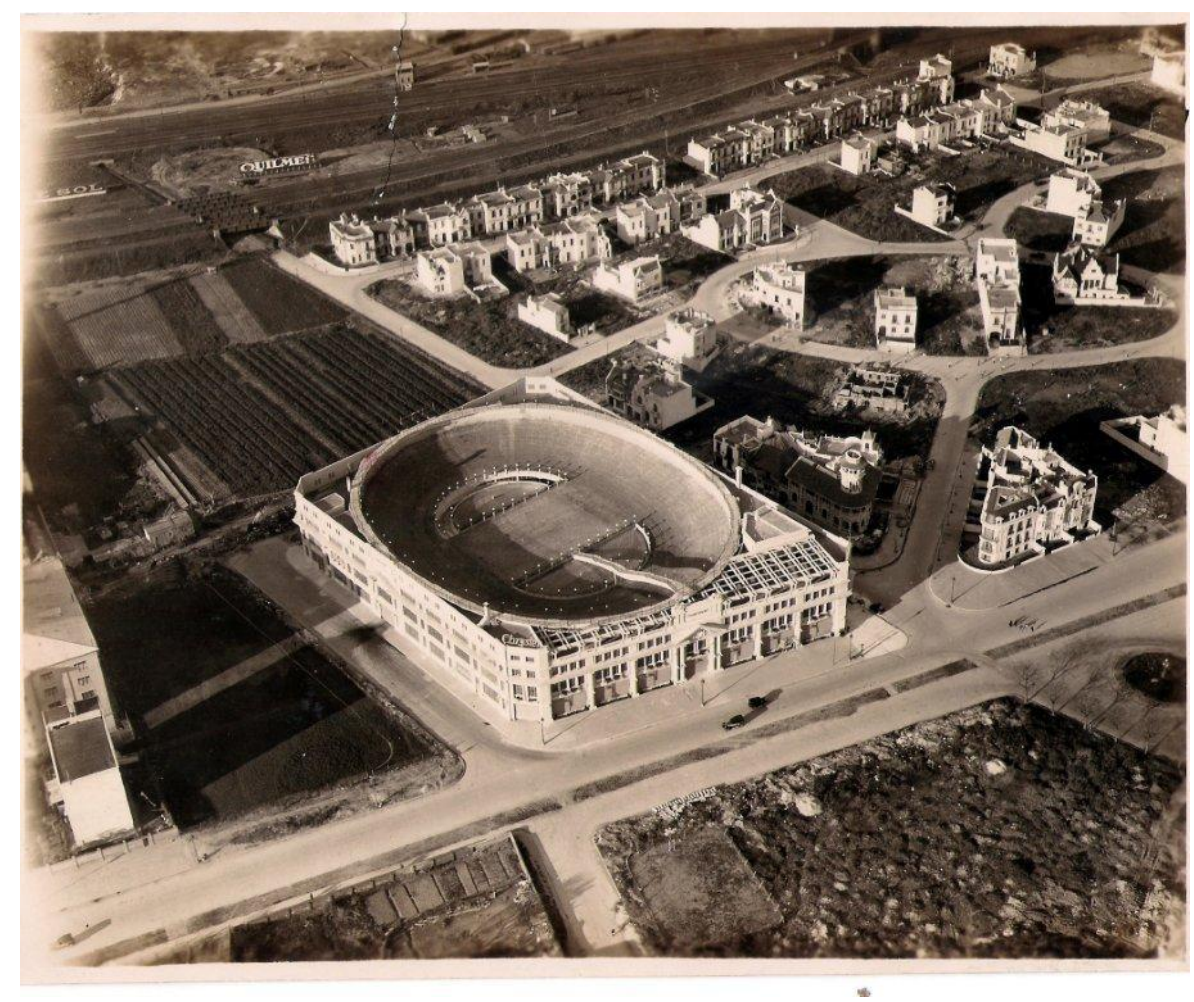

11. Postcard showing Palácio Chrysler, 1928.

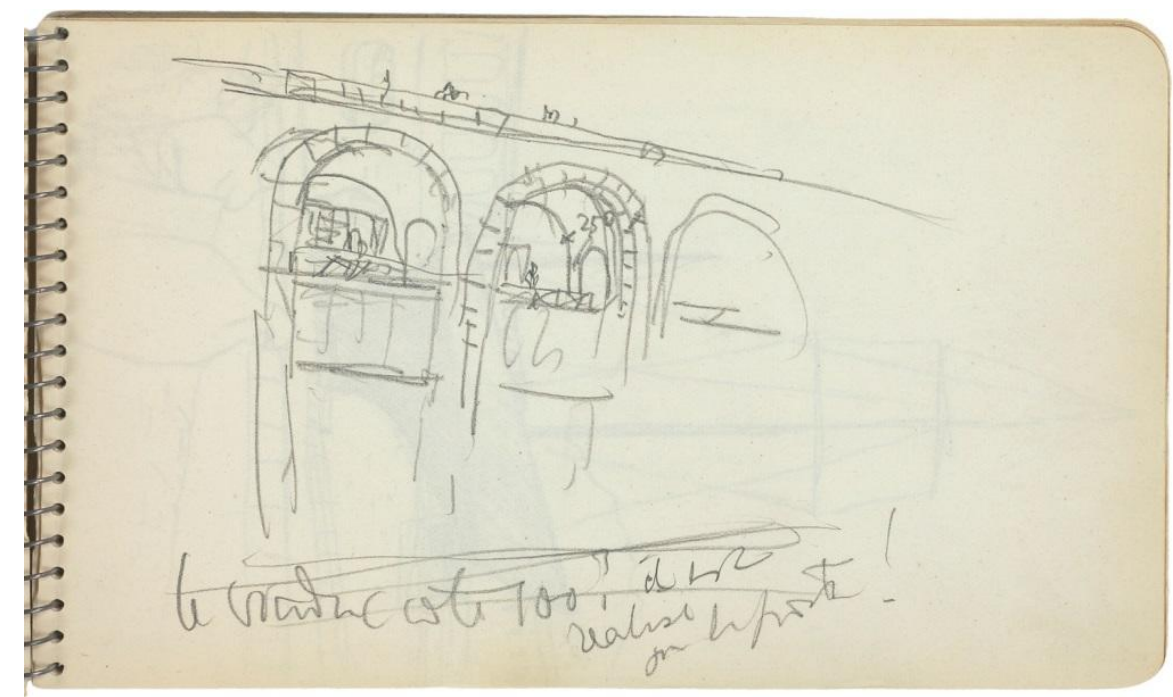

12. Le Corbusier. Arcades des Anglais. 1931. Carnet C10-660. Fondation Le Corbusier, Paris. 


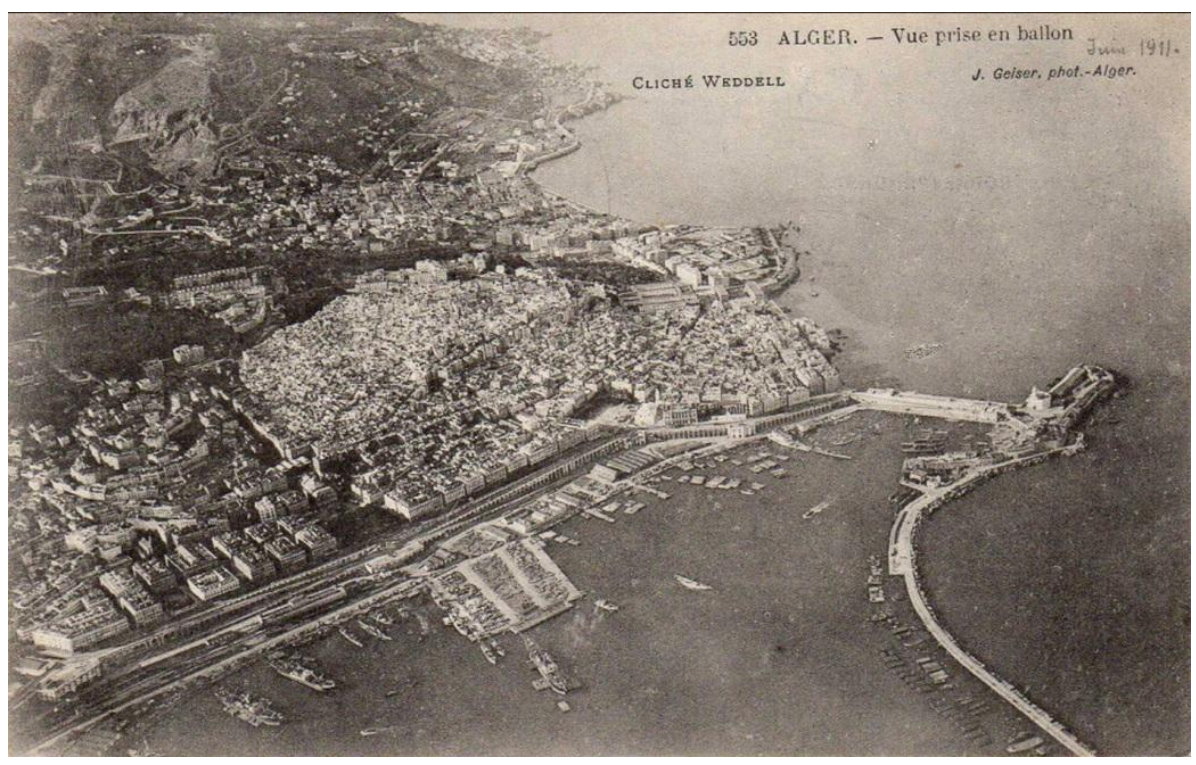

13. Postcard showing Boulevard de la Republique, Algiers.

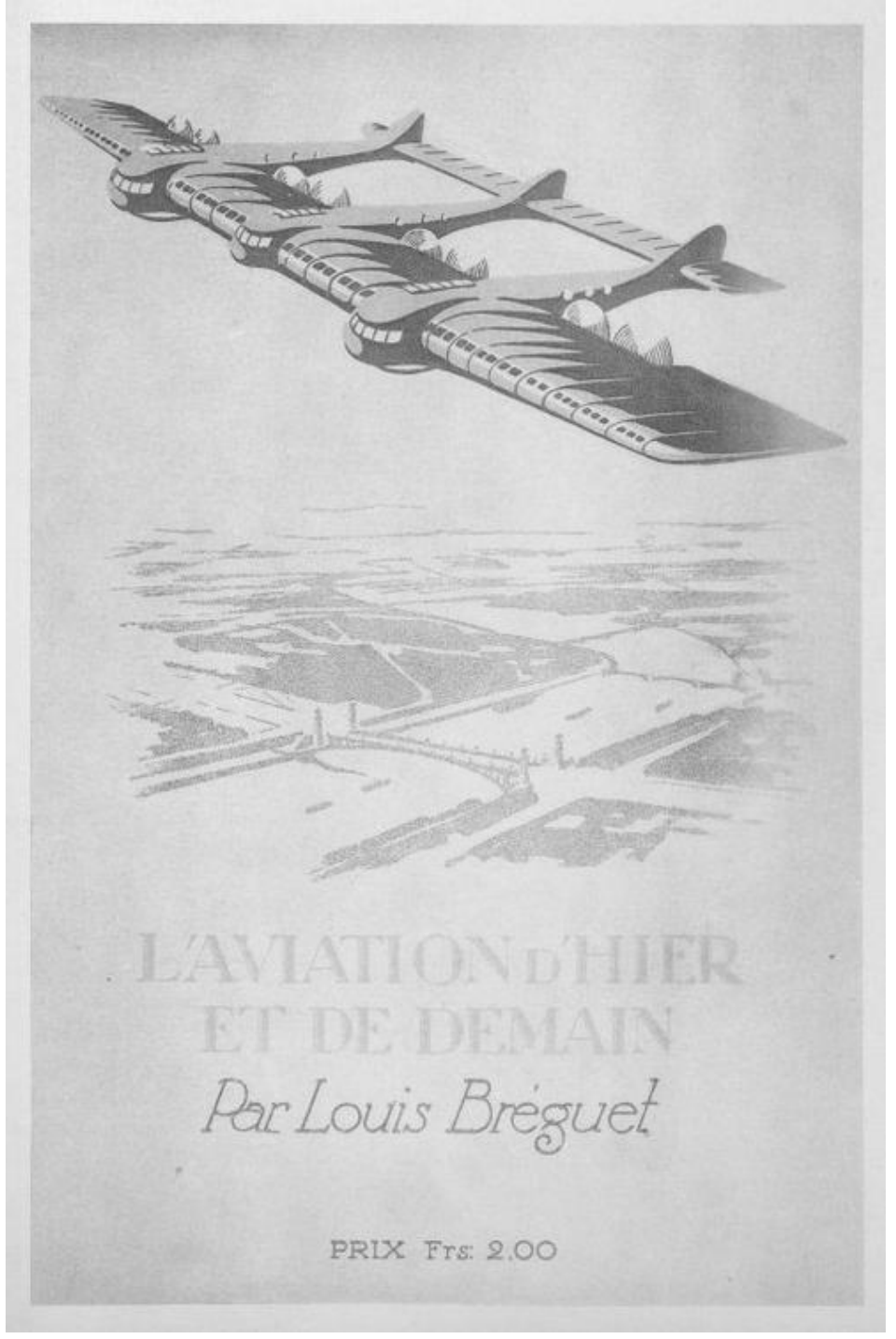

14. Cover of "L'aviation d'hier et de demain", 1922. Bibliothèque Nationale de France. 


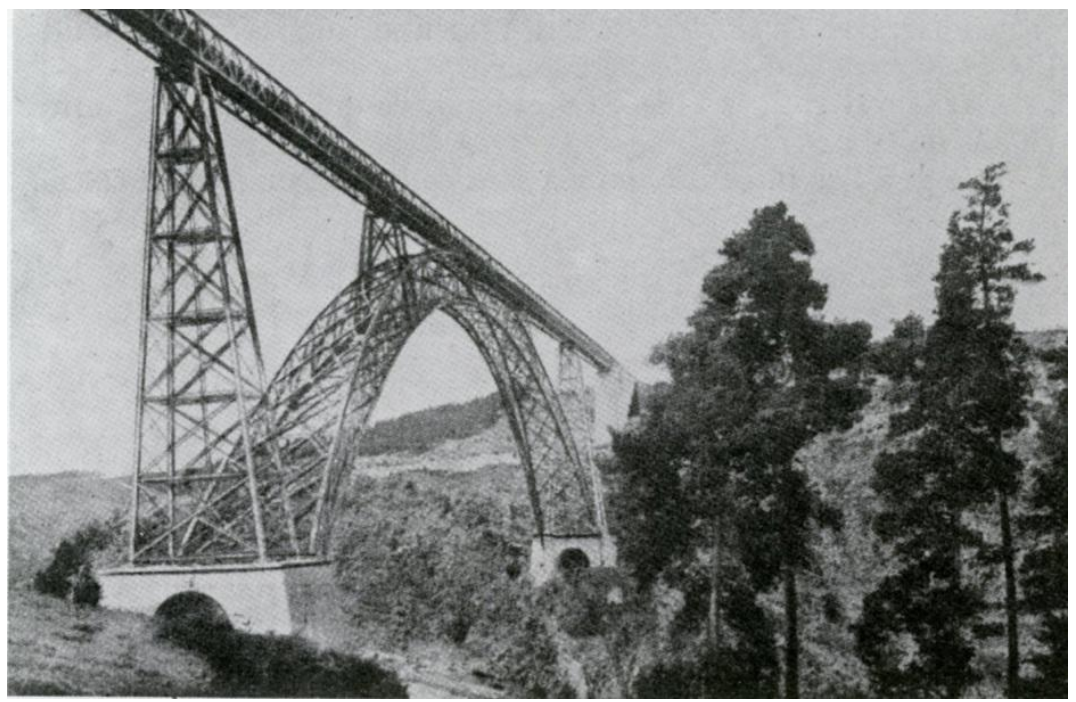

15. Garabit Bridge. From Le Corbusier, "Urbanisme”, (Paris: Crès, 1925), p. 49.

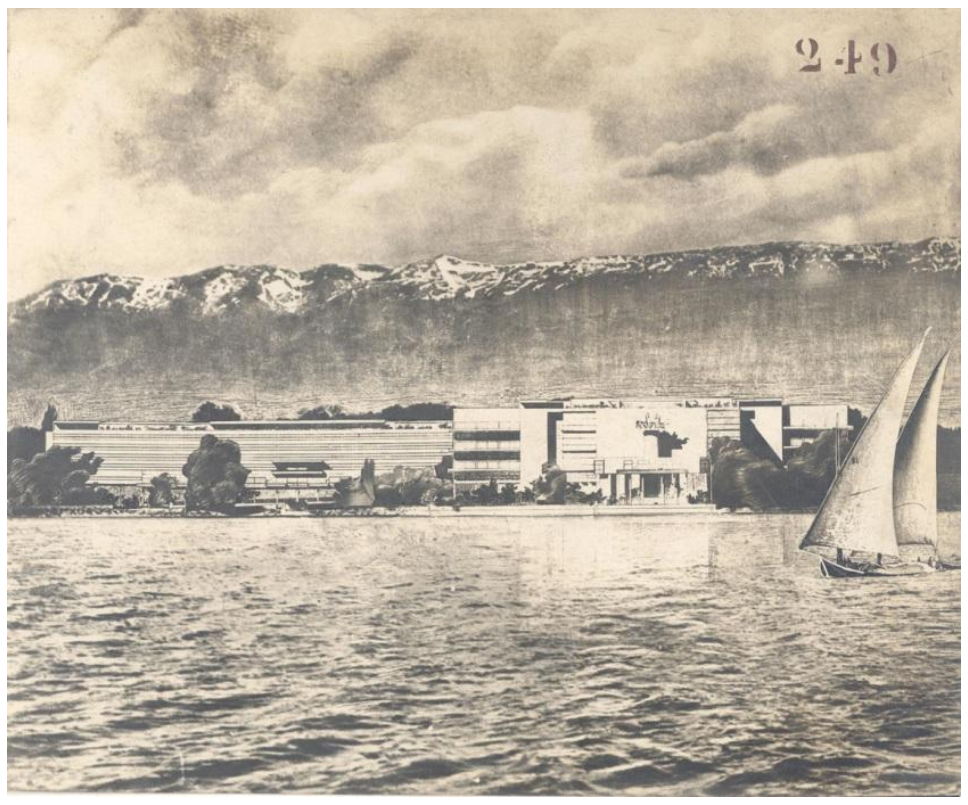

16. Palace of the League of Nations. From Le Corbusier, "Une Maison - Un Palais”, (Paris: Crès, 1928), p. 163.

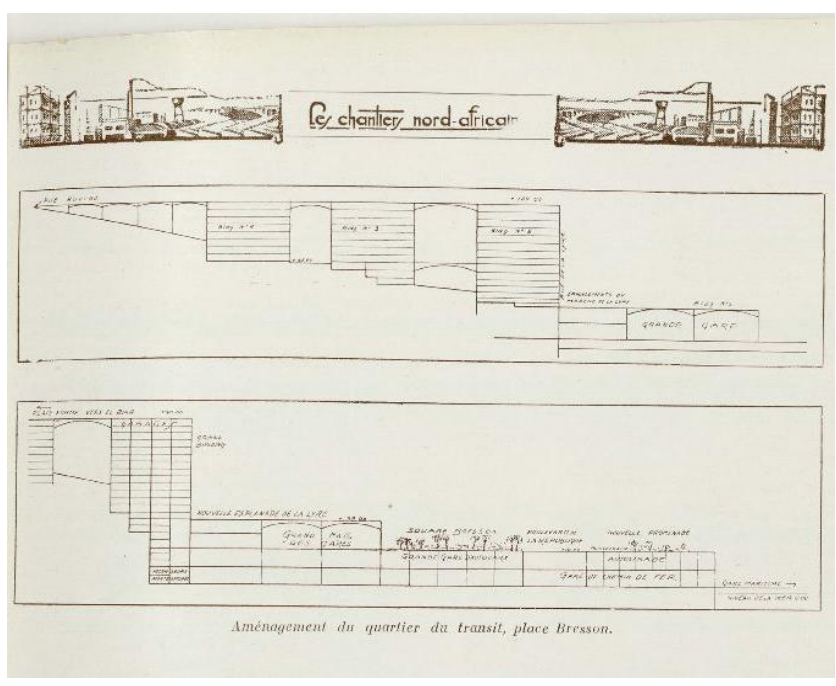

17. Maurice Rotival. Plan for Algiers. Section. From “Chantiers Nord-Africains”, January 1931, p. 35. 


\section{Acknowledgements}

The research for this paper was partly funded by CNPq- Conselho Nacional de Desenvolvimento Científico, Brasil. Victor Tessler, Vanessa Renck and Carlos Eduardo Binato de Castro collaborated in the iconographical research.

\section{Source of images}

Carlos Eduardo Comas collection $(1,11,13)$.

Fondation Le Corbusier @FLC-ADAGP (2, 3, 4, 5, 6, 8, 9, 10, 12, 14, 15).

Bibliothèque Nationale de France (17).

\section{Bibliography/references}

Alonso, Sebastián and others. 5 narrativas, 5 edificios. Montevideo: Ministerio de Educación y Cultura, 2010.

Amado, Antonio. Voiture minimum. Le Corbusier and the automobile. Cambridge, Mass.: The MIT Pres, 2011.

Anderson Jr., John David. A history of aerodynamics and its impact on flying machines. Cambridge: Cambridge University Press, 1997.

Architectural History Foundation; Fondation Le Corbusier. (Eds.) Le Corbusier. Sketchbooks - Vol.1, 19141948. Cambridge, Mass.: MIT Press, 1981.

Banham, Reyner. Theory and Design in the first machine age. London: The Architectural Press, 1960.

Baudelaire, Charles. Le peintre de la vie moderne. Paris: 1863. http://baudelaire.litteratura.com/\#

Boesiger, Willy. Le Corbusier et Pierre Jeanneret. Oeuvre complète de 1929-1934. 13th ed. Zurich: Editions d'Architecture/ Edition Girsberger, 1995.

Boesiger, Willy; Stonorov, Oscar. Le Corbusier et Pierre Jeanneret. Oeuvre complète de 1910-1929. 14th ed. Zurich: Editions d'Architecture/ Edition Girsberger, 1995.

Carlos, Rute Alexandra. A Ville Verte de Le Corbusier como sistema: uma perspectiva centrada no parque . Directorship: Xavier Monteys Roig, Paulo Jorge Souza Cruz. Ph.D. Thesis. Braga, Universidade do Minho, 2013.

Çelik, Zeynep. Urban Forms and Colonial Confrontations: Algiers Under French Rule. Berkeley: University of California Press, 1997.

Cohen, Jean-Louis; Bergdoll, Barry. (Eds.) Le Corbusier. An atlas of modern landscapes New York: MoMA, 2013.

Contreras, Leonel. Rascacielos porteños. Buenos Aires: Gobierno de la Ciudad de Buenos Aires, 2005.

Fondation Le Corbusier. Le Corbusier. Visions d'Alger. Paris: Editions de la Villette, 2012.

Giedion, Sigfried. Space, time and architecture. The growth of a new tradition. Cambridge, Mass.: Harvard University Press, 1941.

Gutierrez, Ramon. (Ed.) Le Corbusier en el Río de la Plata, 1929. Buenos Aires: Cedodal; Montevideo: FARQ Universidad de la Republica, 2009.

Hénard, Eugène. Etudes sur l'architecture et les transformations de Paris \& autres écrits sur l'architecture et l'urbanisme. Preface by Jean-Louis Cohen. Paris: Editions de la Villette, 2013

http://librairie.immateriel.fr/fr/ebook/9782814500396

Hugo, Victor. Notre Dame de Paris. Paris: 1831. 
Le Corbusier, Sur les quatre routes. Paris: Gallimard, 1941.

Le Corbusier. Aircraft. London: The Studio, 1935.

Le Corbusier. La ville radieuse. Éléments d'une doctrine d'urbanisme pour l'équipement de la civilisation machiniste. Boulogne-sur-Seine, France: Éditions de L'Architecture d'aujourd'hui, 1935.

Le Corbusier. Précisions sur un état present de l'architecture et de l'urbanisme. Paris: Vincent, Fréal, 1930.

Le Corbusier. Une maison - un palais. À la recherche d'une unité architecturale. Paris: Crès, 1928.

Le Corbusier. Urbanisme. Paris: Crès, 1925.

Le Corbusier. Vers une architecture. Paris: Crès, 1923.

Liernur, Jorge Francisco; Pschepiurca Pablo. La red austral. Obras y proyectos de Le Corbusier y sus discípulos en la Argetina 1924-1965. Buenos Aires: Universidad Nacional de Quilmes, 2008/

Martin, Leslie; March, Lionel. Urban space and structures. Cambridge: Cambridge University Press, 1972.

Oppositions. 19-20. Winter-Spring 1980.

Paris: publie.net 2010-10-22

Perez Oyarzun, Fernando. (Ed.) Le Corbusier y Suramerica. Santiago: Ediciones ARQ, 1999.

Rodrigues dos Santos, Cecilia, and others. Le Corbusier e o Brasil. São Paulo: Projeto/Tessela, 1987.

Rowe, Colin. The architecture of good intentions. London: Academy Editions, 1994.

Thresholds. 41, Spring 2013.

Tsiomis, Yannis. (Ed.) Le Corbusier. Rio de Janeiro 1929-1936. Rio: Centro de Arquitetura e Urbanismo, 1998. von Moos, Stanislaus. Le Corbusier. Elements of a synthesis. $2^{\text {nd }}$ ed. Rotterdam: 010 Publishers, 2009. 